\title{
Public participation in decentralised governments in Africa: Making ambitious constitutional guarantees more responsive
}

\author{
Oliver N Fuo* \\ Postdoctoral fellow, North West University, Potchefstroom, South Africa
}

\begin{abstract}
Summary
Following the example of South Africa, Kenya, Tunisia and Zimbabwe have recently adopted constitutions that contain bills of rights, embrace the ideals of decentralisation and profess a commitment to participatory democracy. In these countries, different forms of local government are constitutionally protected and accorded some degree of self-governing powers. As part of the state's overarching governance machinery, these governments are obliged to contribute towards the realisation of constitutionally-defined objectives, including a variety of constitutionallyentrenched rights, the pursuit of social justice and sustainable development. As the level of government closest to communities, a local government is constitutionally obliged to facilitate public participation in local governance. In South Africa, the Constitutional Court has interpreted the scope of the government's obligation to facilitate public participation in policy formulation and law-making processes extensively. The article explores the Court's jurisprudence on the nature and extent of the duty to facilitate public participation in order to distil lessons that could guide local authorities in Kenya, Tunisia and Zimbabwe to optimise the quality of public participation in local governance. I argue that, if implemented, guidelines distilled from the Court's jurisprudence could help optimise the quality of public participation at the local level in the various countries.
\end{abstract}

Key words: Decentralisation in Africa; public participation; human rights; Constitutions of Kenya, South Africa, Tunisia and Zimbabwe

* LLB (Hons) (Buea), LLM LLD (North West); njuhfuo@gmail.com. This article was written during the course of the author's post-doctoral fellowship at the North West University. I would like to thank Prof Anel du Plessis and the two anonymous reviewers for commenting on draft versions of the article. 


\section{Introduction}

Over the past three decades there have been several initiatives to promote decentralisation ${ }^{1}$ in different parts of the world. ${ }^{2}$ The commitment towards reinforcing decentralisation can be understood against the background of some of the difficulties faced by central governments to provide public services and to adequately meet the diverse needs of citizens in especially far-flunked areas. ${ }^{3}$ It generally has been argued that, in all cases, decentralisation is expressly or implicitly driven by the need to improve the delivery of basic services such as water, sanitation, health services and education to communities. $^{4}$

Decentralisation in government refers to the restructuring of state authority, in accordance with the principle of (institutional) subsidiarity, ${ }^{5}$ in order to create a system of governance that ensures co-responsibility between institutions of government at the central, regional and local levels, in meeting the needs of citizens. ${ }^{6}$ In other words, central governments relinquish certain functions and powers to lower-level units, such as local authorities that are legally constituted as separate governance bodies. ${ }^{7}$

The general trend towards decentralisation ${ }^{8}$ suggests that local government authorities will increasingly be required to contribute

1 Generally, three forms of decentralisation can be distinguished based on the degree of local government's autonomy in decision making. These are deconcentration, delegation and devolution. See J de Visser Developmental local government: A case study of South Africa (2005) 14-15; R Bird \& F Vaillaincourt (eds) 'Fiscal decentralisation in developing countries: An overview' in R Bird \& F Vaillaincourt Fiscal decentralisation in developing countries (1998) 3-4; EL Yulani 'Decentralization, deconcentration and devolution: What do they mean?' (2011), http://www.cifor.org/ publications/pdf_files/interlaken/Compilation.pdf (accessed 10 March 2012).

2 See $\mathrm{P}$ Reddy 'Local government democratization and decentralization: Theoretical considerations, and recent trends and developments' in P Reddy (ed) Local government democratisation and decentralisation: A review of the Southern African region (1999) 9-10. The following instruments have been adopted to promote decentralisation: the European Charter of Local Self-Government (1985), signed in Strasbourg on 15 October 1985; UN-HABITAT International Guidelines on Decentralisation and Access to Basic Services for All (2009); Final Declaration of the Second Ordinary Session of the All-Africa Ministerial Conference on Decentralisation and Local Development, done at Maputo, Mozambique, on 12 August 2011.

3 | Cloete \& C Thornhill South African municipal government and administration: The new dispensation (2005) 57; J Ahmed et al Decentralisation and service delivery (2005) 1.

4 Ahmed (n 3 above) 1

5 The principle of subsidiarity is considered the underlying rationale of decentralisation. See UN-HABITAT (n 2 above) para 15.

6 UNDP Decentralised governance programme: Strengthening capacity for peoplecentred development (1997) 4.

7 UNDP Decentralisation: A sampling of definitions (1999) 6

8 J Kauzya Political decentralisation in Africa: Experiences of Uganda, Rwanda, and South Africa (2007) 3; Reddy (n 3 above) 9-10. 
towards realising broad national objectives. ${ }^{9}$ In recent years, several African countries have adopted constitutions that establish different forms of decentralised governments and profess commitment towards democratic values, social justice, fundamental human rights and respect for the rule of law. ${ }^{10}$ These constitutions emphasise public participation in government decision-making processes and embrace varying forms of decentralised government as a mechanism for realising defined constitutional objectives. South Africa seems to have set the pace towards this trend on the African continent with the adoption of the Constitution of the Republic of South Africa, 1996. This trend has been followed more recently by Kenya, Tunisia and Zimbabwe. ${ }^{11}$

Through a synthesis of theories and scholarly perspectives, the author elsewhere established ${ }^{12}$ that public participation in local governance is an indispensable requirement for local authorities' pursuit of social justice. ${ }^{13}$ The article explores the South African Constitutional Court's jurisprudence on the nature and extent of the duty to facilitate public participation in order to distil lessons that could guide local authorities in Kenya, Tunisia and Zimbabwe in order to optimise the quality of public participation in local governance. ${ }^{14}$ This approach is motivated by the fact that, unlike the other countries that constitute part of this analysis, the Constitutional Court in South Africa has over the past two decades had opportunities to develop extensively jurisprudence on the right to public participation.

In order to achieve the above objective, the article is divided into four sections. It begins by providing an overview of the constitutional commitment of South Africa, Kenya, Tunisia and Zimbabwe towards decentralisation as a mechanism for realising national objectives and highlighting how the various constitutions have imposed obligations on local authorities to facilitate public participation. The second

9 See UN Report of the UN Summit for Social Development (1995) para 27; S Fainstein 'Competitiveness, cohesion and governance: The implications for social justice' (2001) 25 International Journal of Urban and Regional Research 884-888.

10 See, eg, the Constitutions of South Africa, Kenya, Tunisia and Zimbabwe.

11 This becomes clear from the discussion in part 2 below.

12 See ON Fuo 'Local government's role in the pursuit of the transformative constitutional mandate of social justice in South Africa' unpublished PhD thesis, North West University, 2014.

13 Fuo (n 12 above) 24-64. Several South African authors acknowledge the importance of public participation in government's pursuit of social justice. See $\mathrm{D}$ Brand 'Judicial deference and democracy in socio-economic rights cases in South Africa' (2011) 3 Stellenbosch Law Review 622-625; L Stewart 'The politics of poverty: Do socio-economic rights become real only when enforced by courts?' (2011) IV Diritto Pubblico Comparato ed Europeo 1515.

14 Local governance embraces the duties of local government authorities to 'govern' and 'represent' local communities. To govern in this context means to exercise authority and to have the power to adopt and enforce by-laws, to design and implement policy, to take decisions that can affect the rights of other people, and to exercise discretion in matters of public administration. See AA du Plessis 'Local environmental governance and the role of local government in realising section 24 of the South African Constitution' (2010) 2 Stellenbosch Law Review 275. 
section examines how courts in South Africa, with emphasis on the Constitutional Court, have interpreted the nature and extent of government's duty to facilitate public participation. The third part of the article draws potential lessons from the jurisprudence of South Africa's Constitutional Court that can help local authorities optimise the quality of public participation in Kenya, Tunisia and Zimbabwe. The last section concludes the article.

\section{Sub-national governments and public participation in selected African constitutions}

\subsection{Constitution of the Republic of South Africa, 1996}

The Constitution of the Republic of South Africa, 1996 is considered to be different from liberal classic constitutions or bills of rights in other parts of the world in that it is an engagement with the future that it will partly shape. ${ }^{15}$ It is a constitutional text with a transformative vision aimed at correcting the injustices of the past and establishing a society based on social justice. ${ }^{16}$ This transformative vision is understood as a constitutional commitment which translates into an implicit yet omnipresent constitutional mandate to pursue social justice. ${ }^{17}$ The execution of this mandate is in large part dependent on authorities' respect for and the realisation of a range of rights entrenched in the Bill of Rights. ${ }^{18}$ As such, the constitutional mandate places an obligation on the three spheres of government to realise the rights entrenched in the Constitution to benefit the needs of impoverished people. ${ }^{19}$ All of the rights in the Constitution have the same status in that they are all justiciable. ${ }^{20}$

The Constitution also influenced post-apartheid institutional change. ${ }^{21}$ The result of this institutional change at the government

15 Stewart (n 13 above) 1510. By virtue of globalisation, the future of South Africa will equally be shaped by regional and international trends and developments with respect to, eg, economic growth and job creation.

16 K Klare 'Legal culture and transformative constitutionalism' (1998) 14 South African Journal on Human Rights 153; M Pieterse 'What do we mean when we talk about transformative constitutionalism' (2005) 20 South African Public Law 156161.

17 See A van der Walt 'A South African reading of Frank Michelman's theory of social justice' in $\mathrm{H}$ Botha et al (eds) Rights and democracy in a transformative constitution (2003) 163-164.

18 See Van der Walt (n 17 above) 163-164.

19 See D Brand 'Introduction to socio-economic rights in the South African Constitution' in D Brand \& C Heyns (eds) Socio-economic rights in South Africa (2005) 12-20; M Pieterse 'Eating socio-economic rights: The usefulness of rights talk in alleviating social hardship revisited' (2007) 29 Human Rights Quarterly 796822.

20 Government of the Republic of South Africa \& Others $v$ Grootboom \& Others 2000 (11) BCLR 1169 (CC) para 20.

21 See DJ Brand 'Courts, socio-economic rights and transformative politics' unpublished PhD thesis, University of Stellenbosch, 20094. 
level is a unique, multi-spherical constitutional system of government. ${ }^{22}$ The Constitution established three (national, provincial and local) spheres of government, which are distinctive, interdependent and interrelated and obliged to function in accordance with the constitutional principles of co-operative government. ${ }^{23}$ The three spheres consist of a number of different line functionaries, while the local sphere of government is constituted by 279 municipalities. ${ }^{24}$

Local government, as the sphere of government closest to communities, has been given extensive legislative and executive powers and functions by the Constitution. ${ }^{25}$ This was confirmed by the Court in City of Cape Town \& Others $v$ Robertson \& Others. ${ }^{26}$ In brief, the Court emphasised that municipalities could adopt and implement any measures that foster their developmental mandate, provided such measures do not violate the Constitution and constitutionally-compliant legislation. ${ }^{27}$ The powers of local government also speak to several of the socio-economic rights of local communities. ${ }^{28}$ Unlike other spheres of government, local government is also expressly mandated by the Constitution to fulfil an expanded 'developmental' role. ${ }^{29}$ Although the Court confirmed in Joseph \& Others $v$ City of Johannesburg \& Others ${ }^{30}$ that service delivery remains a central mandate of post-apartheid local government, ${ }^{31}$ municipalities are now required to generally promote sustainable development. ${ }^{32}$ The developmental role of municipalities is captured

22 J Hattingh Governmental relations: A South African perspective (1998) 3. See ch 3 of the Constitution on co-operative government, especially sec 40 .

23 See T Edwards 'Co-operative governance in South Africa, with specific reference to the challenges of intergovernmental relations' 200827 Politeia 65-85; C Kirkby et al 'Towards a more co-operative local government: The challenge of district intergovernmental forums' (2007) 22 South African Public Law 144; L Malan 'Intergovernmental relations and co-operative government in South Africa: The ten year review' 200524 Politeia 226-243.

24 According to sec 151(1) of the Constitution, the local sphere of government comprises of municipalities (metropolitan, district and local) in South Africa. Based on this, the terms 'local government' and 'municipalities' will be used interchangeably. For a complete list of municipalities in the country, see http:// www.demarcation.org.za/ (accessed 5 March 2013).

25 See secs 151(2) and (3) of the Constitution; sec 11(3) of the Local Government Municipal Systems Act 32 of 2000; Fedsure Life Assurance Ltd \& Others v Greater Johannesburg Transitional Metropolitan Council \& Others 199812 BCLR 1458 (CC) para 36.

262005 (2) SA 323 (CC) para 60

27 As above.

28 See I de Visser 'Developmental local government in South Africa: Institutional fault lines' (2009) 2 Commonwealth Journal of Local Governance 11-12; AA du Plessis 'Fulfilment of South Africa's constitutional environmental right in the local government sphere' unpublished LLD thesis, North West University, 2008 141-150 363.

29 See secs 152 and 153(1) of the South African Constitution.

$30 \quad 20117$ BCLR 651 (CC).

31 Joseph (n 30 above) paras 34-40.

32 Fuo (n 13 above) 96-98. 
in the notion of 'developmental local government' which, over time, permeated South Africa's local government law and policy frameworks. ${ }^{33}$ Furthermore, Part B of Schedule 4 and Part B of Schedule 5 of the Constitution outline the areas where local government has 'original' executive and legislative powers including, inter alia, water and sanitation services limited to potable water supply systems and domestic waste water and sewage disposal systems, electricity and gas reticulation, municipal health services, air pollution, building regulations, municipal public transport and childcare facilities. ${ }^{34}$ In addition, in line with the principle of institutional subsidiarity, national and provincial governments can assign additional (new) responsibilities to municipalities. ${ }^{35}$ This means that the range of services provided by municipalities is not confined to the lists contained in Schedules $4 B$ and $5 B$ of the Constitution. ${ }^{36}$ The Pietermaritzburg High Court confirmed this in Le Sueur. ${ }^{37}$

The Preamble to the Constitution purports to lay the foundations for a democratic and open society in which government is based on the will of the people and in which every citizen is equally protected by law. ${ }^{38}$ However, there is no enumerated right to public participation in government decision-making processes in the Bill of Rights. The Constitutional Court has indicated that the right to public/ political participation 'is given effect ... through the political rights guaranteed in section 19 of the Bill of Rights', ${ }^{39}$ as supported by the right to freedom of expression and the duties imposed on government to facilitate public participation and promote democratic and accountable government. ${ }^{40}$

The right to public participation is given considerable importance at the local government level. The Constitution obliges municipalities to provide democratic and accountable government to local communities and to encourage community participation in local government matters. ${ }^{41}$ In addition, section $160(7)$ of the Constitution obliges a municipal council

33 See para 1 of 'Section B: Developmental Local Government' in the White Paper on Local Government (1998) GN 423 in GG 18739 of 13 March 1998.

34 See sec 156 read with Schedules 4B and 5B of the Constitution.

35 See sec 156(4) of the Constitution; J de Visser 'Institutional subsidiarity in the South African Constitution' (2010) 1 Stellenbosch Law Review 90.

36 See City of Johannesburg Metropolitan Municipality v Blue Moonlight Properties 39 (Pty) Ltd \& Another 20122 BCLR 150 (CC) paras 21-97; Le Sueur \& Another $v$ Ethekwini Municipality \& Others (2013) Case 9714/11 paras 19-29.

37 See Le Sueur (n 36 above) para 19

38 See Preamble to the Constitution.

39 Sec 19 of the Constitution guarantees every citizen the right to make political choices.

40 Doctors for Life International v Speaker of the National Assembly \& Others 200612 BCLR 1399 (CC) para 106.

41 See also secs 152(1)(a) and (e) and 195(e) of the Constitution. 
to conduct its business in an open manner, and may close its sittings, or those of its committees, only when it is reasonable to do so having regard to the nature of the business being transacted.

In terms of legislation, the entire chapter 4 of the Systems Act is dedicated to community participation at local government level. The Systems Act obliges municipalities to encourage and create conducive conditions for communities to participate in municipal affairs, including: the preparation, implementation and review of integrated development plans (IDPs); the establishment, implementation and review of performance management systems; the monitoring and review of municipal performance; the preparation of municipal budgets; and strategic decisions relating to the provision of municipal services. $^{42}$ In order to enhance public participation in local governance processes, municipalities are obliged to use their resources and annually allocate funds in their budgets for building the capacity of communities, municipal councils and municipal officials. ${ }^{43}$ By building local capacity, communities may gain the skills needed to participate in local governance processes and hopefully those needed to address some of their daily challenges.

The main vehicles for public participation envisaged by the Systems Act include councillors, ward committees and advisory committees. ${ }^{44}$ Ward committees create a formal and direct communication channel through which community residents can interact with their ward councillors, and forward complaints and suggestions on matters affecting them to the council. ${ }^{45}$ Despite their potential to enrich the content of local policies, it has been indicated elsewhere that many ward committees are dysfunctional. ${ }^{46}$ This has been attributed to the fact that some municipalities face severe resource constraints and some community residents do not take an interest in the operation of ward committees. ${ }^{47}$ The nonchalant attitude of some community members is often borne out by the fact that they have lost confidence in the potential of ward committees to defend their interests or because their capacities have not been fully developed to engage with ward members. 48

The elaborate provisions on public participation at the local level is also extended to people who cannot read or write, people with disabilities, women and other disadvantaged persons. Municipalities are obliged to ensure that the mechanisms, procedures and processes

42 See secs 16(1)(a)(i)-(v) of the Systems Act.

43 See secs 16(1) (b) and (c) of the Systems Act.

44 See secs 17(1)(d) and (4) of the Systems Act; Borbet South Africa (Pty) Ltd \& Others $\checkmark$ Nelson Mandela Bay Municipality 2014 (5) SA 256 (ECP) (3 June 2014) para 18.

$45 \mathrm{~T}$ Smith The role of ward committees in enhancing participatory local governance and development in South Africa: Evidence from six ward committee case studies (2008) 4; O Fuo 'Local government indigent policies in the pursuit of social justice in South Africa through the lenses of Fraser' (2014) 1 Stellenbosch Law Review 205-206.

46 Fuo (n 45 above) 206; Smith (n 45 above) 4-5.

47 Fuo (n 46 above) 206.

48 As above. 
put in place to enhance public participation do not exclude these categories of people. ${ }^{49}$ The emphasis and special attention given to people who cannot read and write is commendable, given the high levels of adult illiteracy in South Africa. ${ }^{50}$ This has the potential of ensuring that the needs and concerns of vulnerable groups of people are reflected in socio-economic policy choices, which will ensure that such policies reflect their lived experiences. Taking into consideration the extensive provisions on the right to public participation at the local government level, De Visser argues that the Systems Act has made 'a concerted attempt to rejuvenate the battered relationship' that existed between the state and society in the old order and that the Act legislates what can be called a 'social pact' between community residents and municipalities. ${ }^{51}$ According to De Visser, the Act 'shows a remarkable commitment to ensuring public participation'.52 The 'elaborate' legal framework on public participation at the local level signals a clear attempt to correct the past that was characterised by exclusionary governance processes and repression. ${ }^{53}$

Despite the legal commitment toward promoting public participation in local governance, effective public participation remains problematic in some municipalities. ${ }^{54}$ Apart from dysfunctional ward committees, De Visser has indicated that some municipal officials have reduced public participation to a more technical exercise driven to merely ensure compliance with the requirements of framework legislation. ${ }^{55}$ In addition, some municipalities often overlook the need for effective public participation in the context of discharging their socio-economic rights obligations. ${ }^{56}$ Although the increasing number of service delivery protests across the country is attributed to different reasons, they are also an indicator of the lack of quality public participation in some local communities. 57

49 See secs 17(3)(a)-(d) of the Systems Act.

50 See J Aitchison \& A Harley 'South African illiteracy statistics and the case of the marginally growing number of literacy and ABET learners' (2006) 39 Journal of Education 89-112.

51 De Visser (n 1 above) 105.

52 As above.

53 As above.

54 See SAHRC Report on the Right to Access Sufficient Water and Decent Sanitation in South Africa: 2014 (2014) 56; Ntombentsha Beja \& Others v Premier of the Western Cape 2011 (10) BCLR 1077 (WCC) paras 81-84 \& 146.

55 De Visser (n 1 above) 106

56 See Occupiers of 51 Olivia Road, Berea Township and 197 Main Street Johannesburg $v$ City of Johannesburg \& Others 2008 (5) BCLR 475 (CC) para 9.

57 For a detailed analysis of this trend, see $\mathrm{P}$ Alexander 'Rebellion of the poor: South Africa's service delivery protests - A preliminary analysis' 201013 Review of South African Political Economy 25-40. 


\subsection{Constitution of Kenya, 2010}

The Constitution of Kenya, 2010 is described as transformative because of its commitment to fundamental social and political change. ${ }^{58}$ It records the commitment of Kenyans to establish a decentralised democratic system of government based on principles of human rights, social justice, good governance and sustainable development. ${ }^{59}$ The Bill of Rights, chapter 4 of the Constitution of Kenya, provides a framework for the country's socio-economic and cultural policies and serves as a mechanism for promoting social justice. ${ }^{60}$ It guarantees a variety of justiciable rights, including the rights to freedom of expression; freedom of association; access to information; to make political choices; to acquire and own property; a clean and healthy environment; the highest attainable standard of health, including the right to health care services, accessible and adequate housing, reasonable standards of sanitation, adequate food, clean and safe water in adequate quantities; education; and social security. ${ }^{61}$ All organs of state are obliged to respect, protect, promote and fulfil the rights in the Bill of Rights. ${ }^{62}$ The Bill of Rights applies to all law and binds all persons and organs of state. ${ }^{63}$

The Constitution of Kenya entrenches the principles of devolution of power and public participation. ${ }^{64}$ It creates two (national and county) levels of government, which are distinct and interdependent and obliged to conduct their mutual relations on the basis of cooperation and consultation. ${ }^{65}$ The entire chapter 11 of the Constitution is devoted to the objects, principles, powers and functions and structures of sub-national (county) governments. The legislative and executive powers of the 47 county governments are constitutionally guaranteed. ${ }^{66}$ According to article 174 , the objects of the devolution of government are to promote democratic and accountable exercise of power; foster national unity by recognising diversity; give powers of self-governance to the people and enhance the participation of the people in the exercise of the powers of the state and in making decisions affecting them; recognise the right of communities to manage their own affairs and further their development; protect and promote the interests and rights of marginalised communities; and promote the provision of easily-

58 NW Orago 'Limitation of socio-economic rights in the 2010 Kenyan Constitution: A proposal for the adoption of a proportionality approach in the judicial adjudication of socio-economic rights disputes' (2013) 16 Potchefstroom Electronic Law Journal 172.

59 See Preamble and art 10(2) of the Constitution of Kenya, 2010.

60 Arts 19(1)-(2) Constitution of Kenya.

61 Arts 33, 35, 36, 38, 40, 42 \& 43 Constitution of Kenya.

62 Art 21 Constitution of Kenya.

63 Art 20(1) Constitution of Kenya.

64 Art 10(2) Constitution of Kenya.

65 Art 6 Constitution of Kenya.

66 See arts 176 (1)-(2), 185 and First Schedule of the Constitution of Kenya, read together with Schedule 4B. 
accessible services throughout the country. In addition, the Constitution provides that, subject to agreement, a specific function can be transferred from one level of government to another level of government if that function would be more effectively performed or exercised by the receiving government. ${ }^{67}$ This provision embraces aspects of the principle of institutional subsidiarity and confirms that, in addition to their constitutional defined powers and functions, local governments can in appropriate circumstances be required to play a broader developmental role. The Constitution requires every county government to decentralise its functions and the provision of its services to the extent that it is efficient and practicable to do so. ${ }^{68}$ Legislation specifies that functions and services of county governments can be decentralised further to urban areas or cities, wards or village units within a county ${ }^{69}$ The ward administrator is expected to co-ordinate, manage and supervise general administrative functions in a ward unit, including the development of policies and service delivery. ${ }^{70}$

The Constitution guarantees that sovereign power rests with the people and that such power can be exercised directly by citizens or indirectly through democratically-elected representatives. ${ }^{71}$ Chapter 11 of the Constitution provides extensively for transparency and public participation at the level of county governments. Each county assembly is obliged to conduct its business in an open manner, to hold its sittings and those of its committees in public and to facilitate public participation and involvement in the legislative and other business of its assembly and committees. ${ }^{72}$ Each county is required to assist and develop the capacity of communities to participate in local governance. ${ }^{73}$ Ward and village administrators are required to coordinate and facilitate the participation of citizens in the development of policies and plans and in the delivery of services at their respective levels. ${ }^{74}$ Part VIII of the County Government Act is dedicated to enhancing public participation at the decentralised level. It outlines, inter alia, principles that inform public participation at the local level, modalities and platforms for public participation, the right of citizens to petition county governments, and the duty of county governments to respond to such petitions. ${ }^{75}$

\footnotetext{
67 See generally sec 187 of the Constitution of Kenya.

68 See generally sec 176(2) of the Constitution of Kenya.

69 See secs 48(1)(a)-(e) of County Government Act 17 of 2012.

70 See generally sec 52 of County Government Act.

71 Arts $1 \& 2$ Constitution of Kenya.

72 Arts 196(1)-(2) Constitution of Kenya.

73 See Function 14 in Part 2 of Schedule 4 of the Constitution of Kenya.

74 See generally secs 51(3)(g) and 52(3)(a)(i)-(ii) of the County Government Act.

75 See generally secs 87-92 of the County Government Act.
} 


\subsection{Constitution of Zimbabwe Amendment Act 20, 2013}

The Constitution of Zimbabwe Amendment Act 20 of 2013 was purportedly introduced to bring about socio-political change in the country. The Constitution expresses the people's commitment to build a just, democratic and prosperous nation founded on the values and principles of constitutional supremacy, the rule of law, fundamental human rights and freedoms, equality and good governance. ${ }^{76}$ Chapter 4 of the Constitution contains a Bill of Rights that guarantees a variety of justiciable human rights. ${ }^{77}$ The rights guaranteed include freedom of assembly and association; freedom to demonstrate and petition; access to information; political rights; property rights; environmental rights; the right to education; the right to health care; the right to food and water; and freedom from arbitrary eviction. ${ }^{78}$ The protection and 'full realisation and fulfilment' of the fundamental rights remains a constitutional objective that should inform the design and implementation of all government policies and legislation in Zimbabwe. ${ }^{79}$ The state is expected to respect, protect, promote and fulfil these rights. ${ }^{80}$ These obligations apply to all levels of government and organs of state. ${ }^{81}$

To bring administration closer to communities and ensure their participation in determining development priorities, local authorities (urban and rural councils) are constitutionally recognised as a third tier of government in Zimbabwe. ${ }^{82}$ Chapter 14 of the Constitution of Zimbabwe deals with the powers and functions of provincial and local government. Section 264 of the Constitution provides that, whenever appropriate, governmental powers and responsibilities must be devolved to provincial and metropolitan councils and local authorities which are competent to carry out those responsibilities efficiently and effectively. ${ }^{83}$ It further states that the objectives for the devolution of governmental powers include the need to give powers of local governance to the people and enhance their participation in the exercise of the powers of the state and in making decisions affecting them; to promote democratic, accountable and transparent government; to recognise the right of communities to manage their own affairs and further their development; to ensure equitable sharing of national and local resources; and to transfer responsibilities and resources from the national government in order to establish a sound financial base for each provincial and metropolitan council and local

\footnotetext{
76 See Preamble and sec 3 of the Constitution of Zimbabwe Amendment Act.

77 Secs 44 \& 45 Constitution of Zimbabwe Amendment Act.

78 Secs 58, 59, 62, $67 \&$ 71-77 Constitution of Zimbabwe Amendment Act.

79 Sec 11 Constitution of Zimbabwe Amendment Act.

80 Sec 44 Constitution of Zimbabwe Amendment Act.

81 Sec 45(1) Constitution of Zimbabwe Amendment Act.

82 See sec 5 and Preamble to ch 14 of the Constitution of Zimbabwe Amendment Act.

83 Sec 264(1) Constitution of Zimbabwe Amendment Act.
} 
authority. ${ }^{84}$ Local authorities are expected to represent and manage the affairs of people in rural and urban areas. ${ }^{85}$ As one of the three tiers of government, local authorities in Zimbabwe are therefore obliged to comply, albeit in varying degrees, with the human rights obligations imposed by the Constitution.

\subsection{Constitution of the Tunisian Republic, adopted on 26 January 2014}

The adoption of the Constitution of the Tunisian Republic on 26 January 2014 legally concretised the ideals of the Jasmine Revolution that started on 17 December 2010. The Preamble to the Constitution expresses the commitment of Tunisians to build a participatory and democratic system of government based on, inter alia, social justice, the rule of law, respect for human rights and freedoms and the sovereignty/will of the people. ${ }^{86}$ The commitment towards social justice and sustainable development is clearly reechoed as a constitutional objective in article 8 of the Constitution. ${ }^{87}$ In line with its commitment towards social transformation, the Constitution of the Tunisian Republic equally guarantees some socioeconomic rights: the rights to social assistance, health care, education, work, water, and a healthy environment. ${ }^{88}$ The Constitution also guarantees the rights of women, children and people with disabilities. ${ }^{89}$

The Constitution further commits the state to strengthen and apply the principle of decentralisation throughout the country. ${ }^{90}$ The entire chapter 7 (also referred to as Title Seven) of the Constitution is dedicated to various aspects of local government. Local government is synonymous to local authorities comprising municipalities, districts and regions that cover the entire country in accordance with legallyestablished boundaries. ${ }^{91}$ Local authorities are headed by elected councils and enjoy a certain degree of self-governing powers 'financial and administrative independence' ${ }^{92}$ Additional powers and functions as well as relevant resources can be transferred from central government to local authorities. ${ }^{93}$ As a co-responsible sphere of government, local authorities can be expected to contribute towards realising the objectives defined by the Constitution, albeit in varying

84 Sec 264(2) Constitution of Zimbabwe Amendment Act.

85 Secs 5(c), $274 \& 276$ Constitution of Zimbabwe Amendment Act.

86 See Preamble and arts 2, 12 and 145 of the Constitution of the Tunisian Republic, adopted on 26 January 2014.

87 Art 12 Constitution of the Tunisian Republic.

88 Arts 38, 39, 40, $44 \& 45$ Constitution of the Tunisian Republic. These rights can be limited in accordance with art 49.

89 Arts 46-48 Constitution of the Tunisian Republic.

90 See art 14 on decentralisation in the Constitution of the Tunisian Republic.

91 Art 131 Constitution of the Tunisian Republic.

92 Arts 132-134 Constitution of the Tunisian Republic.

93 Art 135 Constitution of the Tunisian Republic. 
degrees. Therefore, local authorities can be expected to contribute towards realising entrenched socio-economic rights, the pursuit of social justice and sustainable development.

In line with the commitment towards establishing a participatory democracy, chapter 7 of the Constitution of the Tunisian Republic promotes public participation in local governance. ${ }^{94}$ It requires local authorities to 'adopt the mechanisms of participatory democracy and the principles of open governance to ensure the broadest participation of citizens and of civil society' in the design and implementation of development programmes and land use planning. ${ }^{95}$ In addition, the Constitution places a responsibility on the state (inclusive of local authorities) to provide the necessary conditions for developing the capacities of the youth and supporting them to participate in political (as well as sustainable) development. ${ }^{96}$ Other guaranteed rights closely associated with the right to public participation include the right to freedom of opinion, expression, media and publication; ${ }^{97}$ access to information; ${ }^{\prime 8}$ academic freedom; ${ }^{99}$ elections and vote; ${ }^{100}$ establish political parties, unions and association; ${ }^{101}$ and the right to assembly. ${ }^{102}$

From the above discussion, it is clear that South Africa, Kenya, Zimbabwe and Tunisia have adopted constitutions that profess a commitment to different forms of decentralised government. The constitutions of these countries impose obligations on local authorities to facilitate public participation in local governance.

\section{Duty to facilitate public participation as interpreted by South African courts}

As the discussion below indicates, the Constitutional Court has developed two strands of jurisprudence on the duty of government to facilitate public participation. The first strand relates to the general duty to facilitate public participation in policy formulation and lawmaking processes; and the second specifically relates to situations where there is an imminent threat of eviction. While the former deals with discussions around mutually-acceptable trade-offs and prioritisation in policies and legislation that give effect to people's rights, the latter exclusively deals with instances of planned evictions. The discussion that follows bears this distinction in mind.

\footnotetext{
94 Art 139 Constitution of the Tunisian Republic.

95 As above.

96 Art 8 Constitution of the Tunisian Republic. [ART 8?] I corrected. It is art 8

97 Art 31 Constitution of the Tunisian Republic.

98 Art 32 Constitution of the Tunisian Republic.

99 Art 33 Constitution of the Tunisian Republic.

100 Art 34 Constitution of the Tunisian Republic.

101 Arts 35-36 Constitution of the Tunisian Republic.

102 Art 37 Constitution of the Tunisian Republic.
} 
The most elaborate pronouncements of the Constitutional Court on the general duty of government to facilitate public participation have been made in the context of the duties of parliament and provincial legislatures (the National Council of Provinces). ${ }^{103}$ In Doctors for Life International, the Court indicated that the words 'public involvement' and 'public participation' often are used interchangeably to refer to the 'active participation of the public' in decision-making processes. ${ }^{104}$ The Court explained that the phrase 'facilitate public involvement' is a broad concept which relates to the duty to ensure public participation in government decision-making processes. ${ }^{105}$ Furthermore, the Court asserted that the right to public participation guarantees a positive right of the public to participate in public affairs and a duty on government to facilitate public participation in the conduct of public affairs in order to ensure that this right is realised. ${ }^{106}$

In Doctors for Life International, the Court made it clear that it would not dictate to other branches of government the method to be followed to ensure quality public participation in policy formulation and law making as well as the implementation thereof. ${ }^{107}$ However, it explained that the duty to facilitate public participation has two legs: First, there is the duty to provide meaningful opportunities for public participation in policy formulation and law-making processes and, second, there is the duty to implement measures to ensure that people have the ability to take advantage of the opportunities provided. ${ }^{108}$ According to the Court, these basic requirements could be met where government provides: notice to communities of the issues under consideration and the opportunities for participation that are available; and public education that builds on the capacity of ordinary citizens to meaningfully engage in local government matters. ${ }^{109}$ According to the Court, education and awareness can be achieved, for example, through road shows, community workshops, radio programmes, and publications informing the public about activities of the government. ${ }^{110}$

In Merafong Demarcation Forum \& Others $v$ President of the Republic of South Africa \& Others, ${ }^{111}$ Van der Westhuizen J made it clear that the obligation to facilitate public involvement was open to innovation and may be fulfilled in different ways. ${ }^{112}$ Just as in Fedsure Life, the

103 See, eg, Doctors for Life International; Matatiele Municipality \& Others $v$ President of the Republic of South Africa \& Others (2) 20071 BCLR 47 (CC) paras 50-68.

104 Para 118 Doctors for Life International (n 103 above).

105 Paras 119-129 Doctors for Life International.

106 Para 129 Doctors for Life International.

107 Paras 123-124 Doctors for Life International.

108 Para 129 Doctors for Life International.

109 Para 131 Doctors for Life International.

110 Para 132 Doctors for Life International.

111200810 BCLR 968 (CC).

112 Para 27 Merafong Demarcation Forum (n 111 above). 
Court noted that legislatures and executives in all spheres of government had a discretion to determine how to fulfil the obligation. However, in exercising this discretion, citizens must be given a meaningful opportunity to be heard. The concern of the Court in any given instance is to determine whether government has done what is reasonable in all the circumstances. The method and degree of public participation that is reasonable in a given case depends on a number of factors, including the nature and importance of the legislation/ policy and the intensity of its impact on the public. In any instance, people who stand to be directly affected by government decisions should be given a reasonable opportunity to submit oral and written comments and representations. ${ }^{13}$

In the Merafong case, the Court asserted that, despite the obligation to involve the public in government decision processes, the views of the majority could not always override government policy positions. ${ }^{114}$ Van der Westhuizen J stressed that, although government is certainly expected to be responsive to the needs and wishes of minorities or interest groups, South Africa's constitutional system of government would not be able to function if the legislature (and by extension the executive) were bound by these views. Public participation in government decision-making processes, as envisaged by the Constitution, is supposed to supplement and enhance the democratic nature of general elections and majority rule and not to conflict with or even overrule or veto them. ${ }^{115}$ According to Justice van der Westhuizen, to say that the views expressed during a process of public participation are not binding when they conflict with government's mandate from the national electorate is not the same as cynically stating that the legislature is not required to keep an open mind when engaging in a process of that kind. ${ }^{116}$ Public involvement cannot be meaningful in the absence of a willingness to consider all views expressed by the public. 117 The Court held that public participation requirements aimed to ensure that the legislature is informed of the public's views on the main issues addressed in a Bill and not at the accurate formulation of a legally-binding mandate. ${ }^{118}$ The Court held that the obligation to facilitate public participation was met because the community had a proper opportunity to air their views. ${ }^{119}$

In Borbet South Africa (Pty) Ltd \& Others $v$ Nelson Mandela Bay Municipality, ${ }^{120}$ the Port Elizabeth High Court drew from section 27(4)

113 As above.

114 Para 50 Merafong Demarcation Forum.

115 As above.

116 Paras 53 \& 116 Merafong Demarcation Forum.

117 As above.

118 Para 51 Merafong Demarcation Forum.

119 Paras 59-116 Merafong Demarcation Forum.

120 n 44 above. 
of the Municipal Finance Management Act, $^{121}$ to hold that noncompliance with legal requirements for public participation specifically relating to budgeting processes, including budget approvals, did not render a previously-approved municipal budget (2011/2012) unlawful or invalid. ${ }^{122}$ In plain terms, although the municipality did not meet the requirements for public participation in relation to the adoption of its budget, the adopted budget was not unlawful or invalid. The Court declined to grant an order setting aside the adopted budget in its entirety and an order precluding the respondent from enforcing any claims for recovery against the applicants based on the rates determined in that budget. ${ }^{123}$ This was based on a consideration of the knock-on effect such orders would have on successive - 2012/ 2013 and 2013/2014 - budgets and the significant practical difficulties associated with undoing parts of the budget or of making provision for claims founded upon an order declaring parts or the whole of the budget invalid. ${ }^{124}$ The Court held that to undo the budget process some years after the event would inevitably give rise to significant disruption and uncertainty and that it was not in the interests of justice to do so. ${ }^{125}$

Despite the absence of a remedy with teeth in favour of the applicants, this judgment is significant in that it draws from the rich jurisprudence of higher courts in South Africa, ${ }^{126}$ to expound on the nature and extent of the obligation imposed on municipalities to facilitate participation in local governance. Justice Goosen observed that the obligation to encourage the involvement of communities in local governance extended to all facets of the functioning of the local sphere of government. ${ }^{127}$ He stressed that the obligations imposed on municipalities to facilitate public participation in local governance were extensive and that the use of the phrase 'develop a culture of municipal governance' suggested that a municipal council is obliged to take steps to extend and deepen its democratic processes. ${ }^{128}$ This means that each municipal council must 'create conditions', 'build capacity' and, most importantly, allocate resources to comply with its obligations regarding public participation. The judge went on to indicate that this obligation required each municipal council to take these steps in order to encourage public participation in the preparation and implementation of its Integrated Development Plan

121 Sec 27(4) of the Municipal Finance Management Act 53 of 2003 provides: 'Noncompliance by a municipality with a provision of this chapter relating to the budget process or a provision in any legislation relating to the approval of a budget-related policy does not affect the validity of an annual or adjustments budget.'

122 Paras 92-95 Borbet South Africa (n 120 above).

123 Paras 106-108 Borbet South Africa.

124 As above.

125 As above.

126 Paras 56-71 Borbet South Africa.

127 Para 9 Borbet South Africa.

128 Para 15 Borbet South Africa. 
(IDP) and the preparation of its budget. The obligation to facilitate public involvement also requires municipal councils to communicate information concerning the available mechanisms, processes and procedures to encourage and facilitate community participation. ${ }^{129}$ According to the Court, extensive guarantees for public participation in local government law suggest that municipal councils are to function as the primary spheres of active engagement with members of the community and as the basis upon which participatory democracy is to be founded. ${ }^{130}$ Acknowledging that legislation does not provide a closed list of mechanisms for public participation at the local level, Justice Goosen indicated that community participation must take place through engagement with councils, executive committees and ward committees. ${ }^{131}$ Restating the jurisprudence of the Constitutional Court, Justice Goosen indicated that the obligation to encourage public participation at local government level went beyond a mere formalism in which public meetings are convened and information shared. ${ }^{132}$ This requires meaningful opportunities for participation and that municipalities take steps to ensure that people have the ability and capacity to take advantage of those opportunities. ${ }^{133}$

The above discussion indicates that, due to their proximity to local communities, municipalities carry a higher degree of responsibility in ensuring that community residents participate in the design and implementation of policies and programmes that affect their lives. Local authorities are expected to use their resources to ensure that mechanisms are put in place to ensure public participation and to implement proactive measures that enable citizens to take advantage of the opportunities created for public participation. Local decisions must be informed by concerns raised by communities. However, local authorities cannot be expected to abdicate their governing powers to the public. They have the final say in policy and legislative choices.

The Constitutional Court has specifically developed jurisprudence on what is now referred to as 'meaningful engagement' to guide especially local government officials when effecting evictions. ${ }^{134}$ It should be stressed that this jurisprudence was developed in line with the obligations imposed by section 26(3) of the Constitution ${ }^{135}$ and

129 As above.

130 Para 18 Borbet South Africa.

131 Para 19 Borbet South Africa.

132 As above.

133 As above.

134 Two paragraphs of the discussion on meaningful engagement are reproduced from one of my earlier articles: See ON Fuo 'Constitutional basis for the enforcement of "executive" policies that give effect to socio-economic rights in South Africa' (2013) 16 Potchefstroom Electronic Law Review 16-18. I want to thank the editor of PER for giving me the permission to do so.

135 Sec 26(3) of the Constitution provides: 'No one may be evicted from their home, or have their home demolished, without an order of court made after considering all the relevant circumstances. No legislation may permit arbitrary evictions.' 
relevant housing legislation. ${ }^{136}$ These laws prohibit unlawful evictions of occupiers from state or private property without a court order. In a number of cases, the Court has established that a key factor for determining the fairness of an eviction of persons from private or public property by state authorities is whether they have meaningfully engaged with each other. ${ }^{137}$

In Occupiers of 51 Olivia Road, more than 400 occupiers of two buildings in the inner city of Johannesburg applied for leave to the Court to set aside a judgment of the Supreme Court of Appeal that authorised their eviction by the City. The occupiers argued, among others, that the City did not give them a hearing before deciding to evict them. ${ }^{138}$ The Supreme Court of Appeal based its findings on the fact that the buildings were unsafe and unhealthy. The Supreme Court then ordered the City to provide housing assistance to those in desperate need by relocating them to a temporary settlement area. ${ }^{139}$ After hearing the application for leave to appeal, the Court issued an interim order in which it required that the City and the occupiers should engage with each other meaningfully on certain issues. ${ }^{140}$ Specifically, the interim order obliged the City and occupiers to engage meaningfully, as soon as possible, in order to resolve the difficulties and differences aired in the application before the Court in light of the values of the Constitution, the constitutional and legislative duties of the municipality, and the rights and duties of the citizens concerned; and to alleviate the plight of the occupiers by making the buildings as safe and as conducive to health as is reasonably practicable. The Court ordered the City and the occupiers to submit reports on the results of the engagement, which was taken into consideration in writing the judgment. ${ }^{141}$ As a result of this interim order, an agreement was reached between the City and the occupiers on how to resolve the eviction problems. ${ }^{142}$ Occupiers of 51 Olivia Road therefore illustrates that quality public participation or meaningful engagement at the local government level can be used to find common grounds on challenges that municipalities face in the pursuit of social justice.

In Occupiers of 51 Olivia Road, the Court defined meaningful engagement as a two-way process in which the City and those about to become homeless would talk to each other meaningfully in order to achieve certain objectives. ${ }^{143}$ It held that meaningful engagement

136 Prevention of Illegal Eviction from and Unlawful Occupation of Land Act 19 of 1998; Extension of Security of Tenure Act 62 of 1997.

137 See Port Elizabeth Municipality v Various Occupiers 2004 (12) BCLR 1268 (CC) paras 39-43; Occupiers of 51 Olivia Road (n 56 above) paras $5 \& 14-21$

138 For details on the grounds raised by the occupiers, see para 7 of Occupiers of 51 Olivia Road (n 56 above).

139 Para 1 Occupiers of 51 Olivia Road (n 56 above).

140 Para 5 Occupiers of 51 Olivia Road.

141 As above.

142 Paras 6 \& 25-29 Occupiers of 51 Olivia Road.

143 Occupiers of 51 Olivia Road, para 14. 
has the potential to contribute towards the resolution of disputes and to 'increased understanding and sympathetic care' if both sides are willing to participate in the process. The Court noted that people may be so vulnerable that they may not be able to understand the importance of engagement and may refuse to take part in the process. The Court held that if this happens, a municipality cannot merely walk away but must make reasonable efforts to engage with such vulnerable people and it is only if these reasonable efforts fail that it may proceed without appropriate engagement. The Court stated that, because the engagement process precisely seeks to ensure that a city is able to engage meaningfully with poor, vulnerable or illiterate people, that process should preferably be managed by careful and sensitive people. ${ }^{144}$ It held that the failure of the City to engage with the occupiers was contrary to the spirit and purport of the Constitution, a violation of the right to human dignity, as well as other socio-economic rights obligations imposed by the Constitution. ${ }^{145}$ Yacoob J held that where a municipality's strategy, policy or plan is expected to affect a large number of people, there is a greater need for 'structured, consistent and careful engagement'. ${ }^{146}$ The Court further observed that the process of meaningful engagement could only work if both sides act reasonably and in good faith. ${ }^{147}$ The Court cautioned that community residents who approach the engagement process with an intransigent attitude or with unreasonable and non-negotiable demands may stall the engagement process. On the other hand, municipalities must not perceive vulnerable groups and individuals as a 'disempowered mass', but rather encourage them to be pro-active rather than being purely defensive. The Court expressed the view that civil society organisations that champion the cause of social justice should preferably facilitate the engagement process in every possible way. ${ }^{148}$ Lastly, the Court indicated that secrecy was inimical to the constitutional value of openness and counter-productive to the process of meaningful engagement. ${ }^{149}$ This requires that, in negotiating a policy, plan or programme that affects the rights of communities, municipalities must furnish complete and accurate information that will enable affected communities to reach reasonable decisions. ${ }^{150}$ The objectives of meaningful engagement will differ from one context to another. ${ }^{151}$

144 Para 15 Occupiers of 51 Olivia Road.

145 Para 26 Occupiers of 51 Olivia Road.

146 Para 19 Occupiers of 51 Olivia Road.

147 Para 20 Occupiers of 51 Olivia Road.

148 As above.

149 Para 21 Occupiers of 51 Olivia Road.

150 As above.

151 Para 14 Occupiers of 51 Olivia Road. See also Residents of Joe Slovo Community, Western Cape v Thubelisha Homes \& Others 20099 BCLR 847 (CC) paras 241-242. 
In Port Elizabeth Municipality $v$ Various Occupiers, ${ }^{152}$ the Court assigned itself a managerial role in ensuring that the parties (Port Elizabeth Municipality and 68 occupiers) find mutually-acceptable solutions to their conflicting interests. Writing on behalf of the majority, Sachs I stated that one potentially-dignified and effective mode of achieving sustainable reconciliation of the different interests involved is to encourage and require the parties to engage with each other in a proactive and honest endeavour to find mutuallyacceptable solutions. He asserted that wherever possible, respectful face-to-face engagement or mediation through a third party should replace arms-length combat by intransigent opponents. ${ }^{153}$ The Court expressed the view that in a context such as South Africa where communities have long been divided and placed in hostile camps, mediation had the potential of enabling parties to relate with each other in pragmatic and sensible ways, building up prospects for respectful good neighbourliness for the future. ${ }^{54}$ In addition, the Court indicated that mediation promoted respect for human dignity, underlined the fact that 'we all live in a shared society', contributed towards reducing conflicts between the different parties involved in the process and minimised the expense of litigation. ${ }^{155}$

The Court indicated that in deciding whether it is just and equitable for an eviction order to be made, courts have to consider whether there was an attempt at mediation. ${ }^{156}$ The Court stressed that the housing obligations of municipalities extended beyond the development of housing schemes to treating those within their jurisdiction with respect. The Court stated that where the need to evict people arises, municipalities must make attempts to resolve the problem before seeking an eviction order. ${ }^{157}$ The Court held as follows: ${ }^{158}$

To sum up: In the light of the lengthy period during which the occupiers have lived on the land in the question, the fact that there is no evidence that the Municipality or the owners of the land need to evict the occupiers in order to put the land to some other productive use, the absence of any significant attempts by the Municipality to listen to and consider the problems of this particular group of occupiers, and the fact that this is a relatively small group of people who appear to be genuinely homeless and in need, I am not persuaded that it is just and equitable to order the eviction of the occupiers.

In view of the above finding, the Court held that in all future litigation involving occupiers, courts should be reluctant to accept that it will be just and equitable to order their eviction if it is not satisfied that all

152 Port Elizabeth Municipality (n 137 above).

153 Para 39 Port Elizabeth Municipality.

154 Para 43 Port Elizabeth Municipality.

155 Para 42 Port Elizabeth Municipality.

156 Para 47 Port Elizabeth Municipality.

157 Paras 56 \& 61 Port Elizabeth Municipality.

158 Para 59 Port Elizabeth Municipality. 
reasonable steps had been taken to get an agreed, mediated solution. 159

In Residents of Joe Slovo Community, Ngcobo J asserted that in implementing any relocation programme, the key requirement which must be met is meaningful engagement between the government and residents. ${ }^{160}$ This requirement flows from the need to treat community residents with respect and care for their inherent human dignity as well as the need for government to ascertain the needs and concerns of individual households. ${ }^{161}$ The process of meaningful engagement does not require the parties to agree on every issue. What is required of the parties is that they should approach the engagement process in good faith and reasonableness and should understand the concerns of the other side. ${ }^{162}$ Meaningful engagement can only be achieved if all the parties approach the process in good faith and a willingness to listen and, where possible, to accommodate one another. Justice Ngcobo stressed that the goal of meaningful engagement was to find a mutually-acceptable solution to the difficulties confronting the government and citizens in the quest to realise socio-economic rights. 163 The need for structured and concerted engagement was equally emphasised by Justice Ngcobo when he observed that different messages and perhaps conflicting information from officials of all three spheres of government conveyed to residents of Joe Slovo created misunderstanding and distrust in the minds of the residents regarding the relocation project. ${ }^{164}$ Even though mutual understanding and accommodation of each others' concerns remain the primary focus of meaningful engagement, the decision ultimately lies with government. However, government must ensure that the decision is informed by the concerns raised by the residents during the process of engagement. ${ }^{165}$

In Abahlali Basemjondolo Movement SA \& Another $v$ Premier of the Province of KwaZulu-Natal \& Others, ${ }^{166}$ a majority of the Court found section 16 of the Slums Act, enacted by the KwaZulu-Natal provincial legislature, ${ }^{167}$ to be in violation of the obligations imposed by section 26 of the Constitution. ${ }^{168}$ This is because under section 16 of the Slums Act, the MEC could by notice order any municipality or private landowner to evict unlawful occupiers of slums without due consideration of the requirement of justice and fairness prescribed by

159 Para 61 Port Elizabeth Municipality.

160 Para 238 Joe Slovo (n 151 above).

161 As above.

162 Para 244 Joe Slovo.

163 As above.

164 Para 237 joe Slovo.

165 Para 244 Joe Slovo.

1662010 (2) BCLR 99 (CC). For the facts of this case, see paras 1-10 and 87-91.

167 The details of sec 16 of the Slums Act are outlined in para 103 of Abahlali Basemjondolo (n 166 above).

168 Paras 102-123 Abahlali Basemjondolo (n 166 above). 
the Prevention of Illegal Eviction from and Unlawful Occupation of Land (PIE) Act. ${ }^{169}$ The Court held that section 16 was unconstitutional because it requires a municipality or owner of private property to 'proceed with the eviction of unlawful occupiers even if the PIE Act cannot be complied with'. ${ }^{170}$

In City of Johannesburg Metropolitan Municipality $v$ Blue Moonlight Properties 39 (Pty) Ltd \& Another, ${ }^{171}$ the Constitutional Court declared the City of Johannesburg's housing policy unconstitutional in that it excluded people evicted by a private landowner from its temporary housing programme, as opposed to those relocated by the City. ${ }^{172}$ The Court held that even without assistance from other spheres of government, municipalities were entitled to self-fund housing projects in the realm of emergency situations. ${ }^{173}$ Based on an interpretation of the relevant provisions of the National Housing Code (2009), the Court held that besides its entitlement to approach the province for assistance, the City has both the power and the duty to finance its own emergency housing scheme. It stated that local government must first consider whether it is able to address an emergency housing situation out of its own means and that the City has a duty to plan and budget proactively for situations like those of the occupiers.

In Schubart Park Residents' Association \& Others $v$ City of Tshwane Metropolitan Municipality \& Another, ${ }^{175}$ residents of Block $C$ in Schubart Park, a residential complex owned by Tshwane City, were removed from the residential complex on 21 September 2011 after a fire had broken out. They, together with all other residents returning from work on that day, were denied access to the complex. After failed attempts at the High Court and Supreme Court of Appeal to reoccupy their homes, the applicants approached the Constitutional Court for relief. ${ }^{176}$ The Court had to determine what order was justified in circumstances where residents approached it for the reoccupation of their homes after they had been removed from them in an emergency situation. The Constitutional Court ordered the applicants and respondents to engage meaningfully with each other, through their representatives, in order to ensure that residents of Schubart Park's right to restoration of occupation of their homes was eventually realised. ${ }^{177}$ Schubart Park Residents' Association shows that engagement orders are not limited to situations where they accompany eviction orders, but that they can be made in other circumstances where it is appropriate and necessary.

169 Paras 110-111 Abahlali Basemjondolo.

170 Para 111 Abahlali Basemjondolo.

171 n 36 above. For details of the facts, see paras 1-9.

172 Para 97 Blue Moonlight (n 171 above).

173 Para 57 Blue Moonlight.

174 Para 67 Blue Moonlight.

17520131 BCLR 68 (CC).

176 For details, see Schubart Park Residents'Association (n 176 above) paras 2-38.

177 Paras 42-52 Schubart Park Residents' Association. 


\section{Lessons for local authorities in Kenya, Zimbabwe and Tunisia}

As the South African experience shows, elaborate constitutional, legislative and policy provisions that (a) guarantee the right to public participation in local governance; (b) oblige local authorities to facilitate community participation in local government matters; and (c) create political structures for community participation, do not necessarily translate to active public participation at the grass roots level. In addition to the above measures, it is argued that, in order to realise meaningful public participation at the grass roots level generally, it is important for local authorities to understand the nature of the right to public participation, how to generally facilitate quality public participation in local governance, and how to optimise the potential of local political structures in enhancing public participation. It is submitted that the jurisprudence of South African courts discussed above provides useful lessons, which are outlined below.

In terms of the nature of the right to facilitate public participation in local governance, the preliminary lesson relates to nuances in the formulation of this right and ensuing obligation. As the jurisprudence of the Constitutional Court indicates, despite nuances in phraseology, where the Constitution or enabling law requires that local authorities should 'facilitate', 'promote' or 'involve' local communities in local governance, this should be understood as obliging them to ensure that communities actively take part in local decision-making processes. In the main, the right to facilitate public participation in local government processes should be understood as having two legs: It (a) confers community members a right (as opposed to a privilege) to participate in local government matters; and (b) imposes a duty on local authorities to use their legislative, executive and administrative powers, as well as financial and human resources, to make it easier for community members to participate in the design and implementation of local policies, plans, programmes and laws.

In relation to how community participation should be facilitated in local governance, the jurisprudence of the Court indicates that this requires creativity on the part of local authorities. Based on the nature and potential impact of issues under consideration, local authorities in Kenya, Tunisia and Zimbabwe must explore the most appropriate methods of ensuring that the voices of especially affected communities are heard. However, it is generally submitted that local authorities in these countries will have satisfied the duty to facilitate public participation by (a) providing meaningful opportunities for communities to participate in local decision-making processes; and (b) implementing proactive measures that ensure that communities take advantage of the opportunities created for public participation. Without being prescriptive, local authorities in Kenya, Tunisia and Zimbabwe could optimise the quality of public participation at the local level by providing communities sufficient information on matters 
that are to be considered and the mechanisms and structures that are available for participation, and using their resources to build on the capacity of communities to participate in local decision-making processes. The method and degree of public participation that is required at any given instance should depend on a number of factors, including the nature and importance of the legislation, policy, plan or programme and the intensity of its impact on the public. In any case, those directly affected should be given a meaningful opportunity to make representations and to submit oral and written comments.

The jurisprudence of the High Court in the Borbet case shows that local authorities must clearly communicate, allow for, and enable public participation through (a) their political structures (such as municipal councils and ward committees) and other committees (to which the general public has access); (b) the structures and processes of the local administration mandated to receive petitions and complaints; and (c) forums for community participation in respect of public input into and review of local development programmes. These measures can ensure that established local government structures facilitate active public participation in local decision-making processes.

Despite the constitutional obligation to facilitate public participation, local authorities in Kenya, Tunisia and Zimbabwe must be aware of the fact that they cannot abdicate their governing powers to the public. Public involvement can be largely expected to produce mutually-acceptable trade-offs and at best consensus on local matters. However, consensus or even mutually-acceptable trade-offs are often not attainable. At the end of public consultation, local authorities have the final say. Where mutually-acceptable policy positions cannot be reached, courts may be invited to objectively scrutinise the reasonableness or rationality of a decision taken by local authorities. In this scenario, local authorities must show that they have considered all the views submitted by the public.

In terms of the specific jurisprudence on meaningful engagement, it is submitted that the lessons distilled are directly relevant to Kenya and Zimbabwe. This is because, just as is the case in South Africa, the 2010 Constitution of Kenya expressly guarantees the right of access to adequate housing ${ }^{178}$ while the Constitution of Zimbabwe forbids arbitrary eviction. ${ }^{9}{ }^{9}$ However, it is possible to argue that, because the African Commission on Human and Peoples' Rights (African Commission) has located the right to housing within other rights guaranteed in the African Charter on Human and Peoples' Rights

178 Sec 43(1)(b) of the Constitution of Kenya, 2010 and sec 26 of the Constitution of the Republic of South Africa, 1996.

179 See sec 74 of the Constitution of Zimbabwe Amendment Act. 
(African Charter), ${ }^{180}$ lessons distilled from the jurisprudence on eviction may equally be relevant for local authorities in Tunisia. The African Commission has indicated that a core element of the right to housing is the obligation of each government to refrain from and protect against forced evictions from homes. ${ }^{181}$ Where the need arises for local authorities in Kenya, Tunisia and Zimbabwe to evict community residents in order to implement development projects, for example, it is submitted that, in accordance with lessons emanating from the Court's jurisprudence, they should consider appointing careful and sensitive people to manage the process of engaging affected people, approach the engagement process in good faith and act reasonably, and furnish complete and accurate information about planned evictions. Local authorities should clearly acknowledge government's human rights obligations, including the dignity of people living in poverty, ${ }^{182}$ and should, where possible, forge longterm deliberative partnerships with communities. ${ }^{183}$

\section{Conclusion}

Just as in other parts of the world, countries in Africa are increasingly embracing political decentralisation as a mechanism for promoting the ideals of sustainable development at the local level. The Constitutions of South Africa, Kenya, Tunisia and Zimbabwe have embraced different forms of decentralised governments with express commitments to enhance public participation in local governance. The implementation of these constitutional guarantees will determine the extent to which they positively impact on the lives of local communities. Drawing from the jurisprudence of South Africa's Constitutional Court, this article explores the nature and extent of the duty to facilitate public participation in order to distil lessons that could guide local authorities in Kenya, Tunisia and Zimbabwe to optimise the quality of public participation in local governance. It is argued that local authorities in Kenya, Tunisia and Zimbabwe could draw valuable guidelines from the Court's jurisprudence on public participation, including meaningful engagement, in order to optimise the quality of public participation in local governance.

180 African Commission Principles and Guidelines on the Implementation of Economic, Social and Cultural Rights in the African Charter on Human and Peoples' Rights (2010) paras 77-79.

181 As above.

$182 \mathrm{~S}$ Wilson 'Planning for inclusion in South Africa: The state's duty to prevent homelessness and the potential of "meaningful engagement"' (2011) 22 Urban Forum 281.

183 See G Muller 'Conceptualising "meaningful engagement" as a deliberative democratic partnership' (2011) 22 Stellenbosch Law Review 755-756. 
